\title{
Manfaat buah kurma
}

The sweet and safe date

\author{
Praptiwi, ${ }^{1}$ Dwi Windu Kinanti Arti. ${ }^{1}$
}

* Staf pengajar Fakultas Kedokteran Gigi Universitas Muhammadiyah Semarang

Unversitas Muhammadiyah Semarang, Jl. Kedung Mundu Raya No. 18, Semarang email: praptiwidrg@gmail.com

\begin{abstract}
Abstrak
Latar belakang: Makanan manis, berhubungan dengan kariogenitasnya. Sukrosa merupakan pemanis paling kariogenik dan terbanyak dikonsumsi. Buah kurma banyak mengandung sukrosa, fruktosa, dan glukosa alami. Kandungan tanin dan magnesium di dalam kurma bersifat anti infeksi dan anti inflamasi.

Metode: Penelitian analitik laboratorik dengan rancangan eksperimental ini bertujuan mengetahui beda $\mathrm{pH}$ saliva pasca konsumsi sukrosa, fruktosa, dan kurma. Pelaksanaan penelitian di FKG dan Laboratorium Terpadu Unimus tahun 2016 melibatkan 18 mahasiswa dengan karies $\leq 2$. Diukur pH saliva awal setelah berpuasa $1 / 2$ jam. Selanjutnya berturut-turut $\mathrm{pH}$ pasca kumur air keran, pasca konsumsi $1 \mathrm{~g}$ sukrosa, $1 \mathrm{~g}$ fruktosa, dan 1 butir kurma. Analisis data menggunakan uji t dependent dan one way Anova.

Hasil: pH saliva rerata dan Simpang Baku berturut-turut dari awal, pasca kumur air keran, pasca konsumsi sukrosa, fruktosa, dan kurma sebagai berikut 6,92, SB 0,217; 6,91, SB 0,151; 6,83, SB 0,229; 6,90, SB 0,156; 7,043, SB 0,086. Tidak terdapat beda bermakna $\mathrm{pH}$ saliva awal dengan $\mathrm{pH}$ pasca kumur air keran .Terdapat beda bermakna $\mathrm{pH}$ saliva pasca konsumsi sukrosa, fruktosa, dan kurma ( nilai $\mathrm{p}=0,002 ; \mathrm{p}<$ $0,05)$.
\end{abstract}

Simpulan: $\mathrm{pH}$ saliva pasca konsumsi sukrosa dan fruktosa lebih rendah dibanding kurma. Sukrosa dan fruktosa lebih asam sehingga lebih kariogenik dibanding kurma.

Kata kunci : pH saliva, pasca konsumsi sukrosa, fruktosa, kurma. 


\section{Abstract}

Background: Sweetener is always related to its cariogenecity. White sugar is the most cariogenic sweetener, while date rich of natural sucrose and fructose. Date tannin and magnesium have anti infection and anti inflammation properties. The analytical laboratoric study using experimental design wanted to know the differencies between saliva $\mathrm{pH}$ after consumptions of sucrose, fructose, and date. The study was executed in Faculty of Dentistry and Integrated Laboratory of Muhammadiyah University in Semarang, 2016.

Methods: Sample of study was 18 students of the Faculty having caries $\leq 2$. Initial $\mathrm{pH}$ saliva was measured after $1 / 2$ hour fasting, followed by tap water rinsing, consumptions of $1 \mathrm{~g}$ sucrose, $1 \mathrm{~g}$ fructose, and a date.

Result: Tdependent test, and one way Anova were used. Mean of saliva $\mathrm{pH}$ and SD were found consecutively as follows, initial 6.92; 0.217 ; tap water rinsing 6.91; 0.151, sucrose consumption 6.83; 0.229 , fructose $6.90 ; 0.156$, and date $7.04 ; 0.086$. No significant difference between initial $\mathrm{pH}$ and after tap water rinsing. There was significant difference between saliva $\mathrm{pH}$ after sucrose, fructose, and date consumptions ( $\mathrm{p}$ value $0.002 ; \mathrm{p}<0.05$ ).

Conclusion: Saliva $\mathrm{pH}$ after consumptions of sucrose and fructosa were lower than date; sucrose and fructose were more acidic and cariogenious than date.

Key words : Saliva $\mathrm{pH}$, after sucrose consumption, fructose consumption, date consumption.

\section{PENDAHULUAN}

Tingginya kejadian penyakit infeksi sebagai penyebab kematian di Indonesia, antara lain disebabkan oleh infeksi di dalam rongga mulut. Keadaan tersebut terutama ditimbulkan oleh gigi karies sebagai fokus infeksi. ${ }^{1}$ Riset Kesehatan Dasar (RISKESDAS) tahun 2013 menyatakan, bahwa pada anak usia $\geq 12$ tahun di JawaTimur yang bebas karies terdapat sebesar $49,8 \% .^{2}$

Karies gigi disebabkan oleh karbohidrat yang sangat berpengaruh pada kesehatan sistemik dan status gizi. Penyebab karies gigi meliputi inang yaitu gigi dan saliva, plak, substrat / diet, dan waktu. ${ }^{3,4}$

Karbohidrat terutama gula pasir atau refined carbohydrate sukrosa diabsorbsi oleh plak. Bakteri plak memetabolisasi karbohidrat tersebut dan memroduksi asam. Bila asam terlalu tinggi, atau $\mathrm{pH}$ terlalu rendah, demineralisasi email terjadi, menginisiasi proses karies. ${ }^{3,5}$ Sukrosa hasil refining tersebut merupakan jenis gula yang paling kariogenik dan sampai sekarang terbanyak dikonsumsi. ${ }^{6}$ Kurma adalah buah yang manis, banyak mengandung sukrosa, fruktosa, dan glukosa alami. Tanin dalam kurma bersifat anti infeksi dan anti inflamasi, kalsium dalam kurma sangat penting untuk pertumbuhan gigi, sedang kandungan zat besi dan kalium diperlukan untuk menetralisir cairan tubuh bila berada dalam kondisi asam. ${ }^{7}$

Saliva sebagai pertahanan alami dalam mulut, mencegah proses demineralisasi. ${ }^{8}$ Cairan ini meningkatkan remineralisasi dalam email maupun dentin. ${ }^{5}$ Saliva mempertahankan integritas email gigi dengan mengatur remineralisasi dan demineralisasi. ${ }^{9}$

dari uraia di atas peneliti ingin mengetahui beda $\mathrm{pH}$ saliva pasca konsumsi sukrosa dan fruktosa dengan pasca konsumsi kurma.

Karies gigi merupakan salah satu penyakit menular yang umum diderita oleh manusia, dan sulit diberantas. ${ }^{10}$ Karies gigi merupakan penyakit yang agresif dan ireversibel. Penyakit tersebut menyerang jaringan gigi dengan karakteristik demineralisasi bagian anorganik dan kerusakan bagian organik gigi. Faktor-faktor penting penyebab karies gigi adalah bakteri Streptokokus mutans, Laktobasili, kecepatan alir saliva, dan $\mathrm{pH}$ saliva. Karies juga dimodifikasi oleh faktor diet, serta pemeliharaan higiene mulut dan gigi yang tergantung pada status sosial ekonomi. ${ }^{11,12}$ Karies pada anak bisa banyak dikurangi melalui diet rendah refined carbohydrate dengan ketat. ${ }^{13}$ Gula atau karbohidrat yang bisa difermentasi di dalam mulut akan menurunkan 
$\mathrm{pH}$ plak oleh asam organik yang meningkatkan kelarutan kalsium hidroksi apatit email. Kalsium hilang dari permukaan gigi, disebut demineralisasi. $^{5}$

Gula adalah karbohidrat yang terasa manis, terdiri atas monosakarida dan atau disakarida. Pemanis atau gula mencakup gula tebu, gula merah, gula bit, dan lain-lain. Sukrosa merupakan refined sugar, berasal dari tebu dan bit. Gula tersebut paling kariogenik dan paling banyak dikonsumsi oleh manusia. Refined sugar mengandung energi tinggi, tetapi tidak bergizi, ${ }^{6}$ berbeda dengan keadaan aslinya yaitu gula tebu atau gula bit. Gula meningkatkan keasaman dalam mulut, juga lambung dan darah. Bila $\mathrm{pH}$ menjadi 5,5 email mulai terlarut. Sesudah mengkonsumsi gula, $\mathrm{pH}$ saliva menurun sampai 4,5 dan email banyak yang terlarut. ${ }^{6}$

Untuk mendapatkan pemanis yang aman dikonsumsi, telah dipelajari buah kurma atau Phoenix dactylifera. Buah tersebut banyak mengandung sukrosa, fruktosa, dan glukosa alami. Tanin yang terkandung dalam kurma bersifat anti infeksi, sedang magnesiumnya merupakan agen anti inflamasi, ${ }^{14}$ penting untuk pertumbuhan tulang. Vitamin $\mathrm{K}$ dalam kurma penting dalam proses penjendalan darah dan metabolisme tulang. ${ }^{8}$ Kariogenitas suatu pemanis dapat diukur menggunakan indikator keasaman atau $\mathrm{pH}$ saliva. Kelompok bebas karies berhubungan dengan $\mathrm{pH}$ saliva yang tinggi, ${ }^{15}$ sedang kelompok dengan karies tinggi mempunyai $\mathrm{pH}$ saliva yang rendah. ${ }^{9}$

Saliva merupakan bagian dari sistem pertahanan tubuh yang sebagian besar terdiri dari air. ${ }^{12}$ Kandungan saliva selain air adalah sel epitel rongga mulut yang mengalami deskuamasi, mikroorganisme dan produknya, leukosit, serum, cairan antara gigi dan gingiva bebas, dan sisa makanan. Orang sehat memroduksi $1-1,51$ dengan sekresi sekitar $750 \mathrm{ml}$ dalam sehari semalam. Sekret yang dihasilkan oleh kelenjar submandibula sebesar $60 \%$, kelenjar parotis $30 \%$, sisanya berasal dari kelenjar sublingual. ${ }^{9}$

$\mathrm{pH}$ normal saliva berada dalam kisaran 6,2 - 7,6 dengan rerata 6,7. Bila keadaan mulut terlalu asam, terjadi demineralisasi, email menjadi porous, sehingga akhirnya terbentuk karies. Ketika saliva menjadi lewat jenuh oleh kalsium dan fosfat pada $\mathrm{pH}=7$, terjadi deposit kalsium Proses remineralisasi oleh saliva akan memperbaiki kerusakan oleh demineralisasi, walaupun memerlukan waktu lama. ${ }^{9}$ Pertahanan oleh saliva terjadi melalui 2 mekanisme, yaitu aliran saliva mengurangi karbohidrat yang dimetabolisasi bakteri, kemudian membuang asam yang diproduksi. Mekanisme lain adalah saliva menetralisir keasaman yang berasal dari minuman, makanan, dan aktivitas bakteri. ${ }^{12}$

Sekretori imunoglobulin A adalah komponen imunologik terbesar dalam saliva. Protein saliva non imunologik diantaranya adalah enzim lisozim dan laktoferin, mucin glikoprotein, aglutinin, histatin, prolin, dan sistatin. Lisozim menghidrolisis dinding berbagai jenis bakteri. Laktoferin berikatan dengan zat besi bebas dalam saliva, menimbulkan pengaruh bakterisid dan bakteriostatik pada bakteri yang membutuhkan zat besi untuk hidupnya, contoh Streptokokus mutans. ${ }^{9}$ pH saliva sebagai indikator keasaman rongga mulut memudahkan pengukuran, tidak invasif dan tidak menimbulkan stres. Sebaliknya, penggunaan $\mathrm{pH}$ saliva tersebut bisa menimbulkan kontaminasi dalam rongga mulut, serta keadaan dehidrasi. ${ }^{16}$

\section{METODE PENELITIAN}

Jenis penelitian adalah analitik laboratorik dengan rancangan eksperimental dengan populasi mahasiswa dan mahasiswi FKG Unimus sebanyak 196 orang. Sampel adalah 18 mahasiswa dan mahasiswi dengan karies gigi $\leq 2$. Sampel diambil secara accidental. Variabel bebas penelitian adalah Konsumsi sukrosa, konsumsi fruktosa, dan konsumsi kurma. Variabel terikat adalah $\mathrm{pH}$ saliva.

Pengumpulan data dilakukan dengan cara: setengah jam sebelum pengambilan saliva awal, sampel puasa, tidak makan, tidak minum, tidak berkumur, dan tidak menggosok gigi. Tanpa stimulasi, sampel menelan saliva 2 kali, selanjutnya diminta mengeluarkan saliva. Saliva ditampung di kantung plastik yang telah diberi label dengan nomor, nama / inisial sampel, dan tahap. Tahap -tahap terdiri dari tahap saliva awal, tahap berkumur dengan air keran setempat / Laboratorium, tahap konsumsi sukrosa, tahap konsumsi fruktosa, dan tahap konsumsi kurma. Saliva awal di dalam kantung plastik segera diukur pHnya dan dicatat. Kegiatan berikutnya adalah sampel berkumur dengan air keran, dan diukur $\mathrm{pH}$ salivanya sama seperti cara pada $\mathrm{pH}$ awal. Tahap ini perlu dilakukan untuk mendapatkan kepastian ada atau tidak ada pengaruh air keran pada $\mathrm{pH}-\mathrm{pH}$ yang akan diukur, karena pasca konsumsi sukrosa, juga 
fruktosa, sampel menggosok gigi dengan menggunakan air keran. Aktivitas menggosok gigi tersebut dilakukan tanpa meng-gunakan pasta gigi, agar tidak ada kemungkinan pengaruh komponen-komponen pasta gigi pada saliva yang akan diukur pHnya.Sampel kemudian mengkonsumsi sukrosa, menelan saliva 2 kali, mengeluarkan saliva dan ditampung dalam kantong plastik, mengukur $\mathrm{pH}$ nya dan dicatat, lalu menggosok gigi tanpa pasta gigi. Aktivitas selanjutnya, konsumsi fruktosa sampai dengan pengukuran $\mathrm{pH}$ saliva dan menggosok gigi. Selanjutnya adalah konsumsi kurma sampai dengan pengukuran $\mathrm{pH}$ saliva. Pencatatan $\mathrm{pH}$ saliva mendapatkan nilai $\mathrm{pH}$ saliva awal, $\mathrm{pH}$ saliva pasca kumur air keran, $\mathrm{pH}$ saliva pasca konsumsi sukrosa, $\mathrm{pH}$ saliva pasca konsumsi fruktosa, dan $\mathrm{pH}$ saliva pasca konsumsi kurma.

Alat yang digunakan meliputi timbangan neraca elektrik, $\mathrm{pH}$ meter digital untuk saliva merk Lovibond Senso Direct buatan Jerman, kantong plastik, sikat gigi, dan kertas label; sedangkan bahan yang digunakan meliputi kapas, alkohol 70\%, sukrosa p.a, fruktosa p.a, dan kurma.

Analisis univariat dalam penelitian, merupakan deskripsi perolehan $\mathrm{pH}$ saliva. $\mathrm{pH}$ tersebut meliputi $\mathrm{pH}$ saliva awal, $\mathrm{pH}$ saliva pasca kumur air keran, $\mathrm{pH}$ saliva pasca konsumsi sukrosa, $\mathrm{pH}$ saliva pasca konsumsi fruktosa, dan $\mathrm{pH}$ saliva pasca konsumsi kurma. Data $\mathrm{pH}$ saliva tercatat dalam rerata dan Simpang baku.

Analisis penelitian menggunakan uji statistik t- dependent untuk menguji beda $\mathrm{pH}$ saliva awal dengan $\mathrm{pH}$ saliva pasca kumur air keran dan uji Anova menganalisis beda $\mathrm{pH}$ saliva pasca konsumsi sukrosa, $\mathrm{pH}$ saliva pasca konsumsi fruktosa, dan $\mathrm{pH}$ saliva pasca konsumsi kurma.

\section{HASIL DAN PEMBAHASAN}

$\mathrm{pH}$ saliva ke18 sampel, yaitu $\mathrm{pH}$ awal, $\mathrm{pH}$ pasca kumur air keran, $\mathrm{pH}$ pasca konsumsi sukrosa, $\mathrm{pH}$ pasca konsumsi fruktosa, dan $\mathrm{pH}$ pasca konsumsi kurma, diukur segera sesudah mengunyah, menelan, dan mengeluarkan saliva. $\mathrm{pH}$ saliva diukur menggunakan $\mathrm{pH}$ meter digital. Nilai - nilai $\mathrm{pH}$ saliva tersebut dalam rerata dan Simpang Baku terlihat pada Tabel 1.
Tabel 1. pH saliva sampel

\begin{tabular}{lcc}
\hline & \multicolumn{2}{c}{ pH saliva } \\
\cline { 2 - 3 } & Rerata & Simpang Baku \\
\hline $\mathrm{n}=18$ & 6,9194 & 0,2175 \\
Saliva awal & 6,9106 & 0,1512 \\
pasca kumur air keran & 6,8350 & 0,2298 \\
pasca konsumsi sukrosa & 6,9011 & 0,1560 \\
pasca konsumsi fruktosa & 7,0428 & 0,0863 \\
pasca konsumsi kurma & & \\
\hline
\end{tabular}

pH saliva awal dan pasca kumur air keran, dianalisis dengan uji $\mathrm{t}$ dependent tidak memberikan beda bermakna (nilai $\mathrm{p}=0,866 ; \mathrm{p}>0,05$ ).

Hasil analisis tersebut menunjukkan bahwa air keran tidak memberikan perubahan pada tingkat keasaman air ludah, yaitu $\mathrm{pH}$ saliva awal. Pada perlakuan-perlakuan selanjutnya, sebagai contoh adalah konsumsi sukrosa yang sebelumnya sampel berkumur air keran. Sebelum mengkonsumsi fruktosa, sampel gosok gigi tanpa pasta gigi dan menggunakan air keran juga. Hasil analisis statistik yang pertama diatas menjadikan dasar keyakinan tentang tidak terpengaruhnya hasil pengukuran $\mathrm{pH}$ lebih lanjut oleh pengaruh air keran.

Uji Anova untuk menganalisis beda $\mathrm{pH}$ saliva pasca konsumsi sukrosa, fruktosa, dan kurma, mendapatkan beda bermakna (nilai $\mathrm{p}=0,002 ; \mathrm{p}<0,05) . \mathrm{pH}$ saliva kurma, reratanya tertinggi dibanding sukrosa dan fruktosa. Keadaan ini terdukung oleh penelitian Pandey et al (2015) yang menemukan bahwa kelompok bebas karies berhubungan dengan $\mathrm{pH}$ saliva yang tinggi. ${ }^{17} \mathrm{pH}$ saliva yang tinggi menunjukkan keadaan basa dalam mulut. Kondisi ini kemungkinan disebabkan oleh tingginya kadar kalsium dan fosfat pada $\mathrm{pH} \mathrm{7,} \mathrm{sehingga} \mathrm{terjadi}$ deposit kalsium. ${ }^{5} \mathrm{pH}$ saliva pasca konsumsi kurma yaitu $>7$ terdukung oleh pernyataan Moynihan (2004) tersebut.

Faktor-faktor penting penyebab karies gigi, diantaranya adalah bakteri Streptokokus mutans dan Laktobasilus. ${ }^{12}$ Bakteri-bakteri tersebut menimbulkan inflamasi dan infeksi, yang mendapat perlawanan berturut-turut oleh magnesium dan tanin dalam kurma. ${ }^{14}$

\section{SIMPULAN}

$\mathrm{pH}$ saliva pasca konsumsi sukrosa dan fruktosa lebih rendah dibanding kurma. Sukrosa 
dan fruktosa lebih asam sehingga lebih kariogenik dibanding kurma

\section{DAFTAR PUSTAKA}

1. Astroth J. The links between oral and Systemic health. Issue of Clinical Advisor. 2009 March:1-3.

2. Fakultas Kedokteran Gigi Universitas Airlangga. Proposal Seminar Training of Trainer Oral Health Survey berbasis WHO Standard. 2017.

3. Hebbal M, Ankola AV, Metgud SC. Dental caries, salivary parameters and plaque scores as caries risk predictors among 12 year old school children. A follow up study. International Journal of Collaborative Research on Internal Medicine and Public Health.2012 vol 4 no 5.

4. Widowati W, Akbar SH, Tin MH. Saliva $\mathrm{pH}$ changes in Patients with High and Low caries risk after Consuming organic (Sucrose) and Non-organic (Maltitol) sugar. 2013.

5. Moynihan P, Petersen PE. Diet, nutrition and the prevention of dental diseases. Public Health Nutrition: 2004; 7(1A), 201-226.

6. The Doctor Within.com. Sugar: The sweet thief of life. 2015.

7. Rudrappa U. Dates nutrition facts. www.nutrition-and-you.com. 2015.

8. Gopinath VK, Arareanne AR. Saliva as a Diagnostic Tool for Assessment of Dental Caries.Archivesof Orofacial. 2006.

9. De Almeida PDV, Gregio AMT, Machado MA, de Lima ADS, Azevedo LR. Saliva Composition and Functions: A comprehensive review. The Journal of Contemporary Dental Practice. 2008. 228; Vol 9, no 3.
10. Ahmadi - Motamayel F, Goodarzi MT, Hendi SS, Abdolsamadi $\mathrm{H}$, Rafieian N. Evaluation of salivary flow rate, $\mathrm{pH}$, buffering capacity, calcium and total protein levels in caries free and caries active adolescence. J of Dent and Oral Hyg. 2013 Vol 5(4): 35-39.

11. Guerrieri A, Gauscher C, Bonte E, Lasvargues JJ. Minimum intervention dentistry: part 4. Detection and Diagnosis of Initial caries lesions. British Dental Journal 213, 2012; 551-557. Baliga S, Muglikar S, Kale R. Salivary pH: a diagnostic biomarker. J Indian Soc Periodontol 2013;17(4):461-465.

12. Yadav P, Bakshish K, Srivastava R, Srivastava S. Sugar substitutes and health. IOSR Journal of Dental and Medical Sciences 2014 vol 13(8) III:68-75.

13. Barrett M. Health benefits of dates Promoting heart, brain, and digestive health. Organic facts. 2013.

14. Pandey P, Reddy NV, Rao V, Saxoena A, Chaudhary CP. Estimation of salivary flow rate, $\mathrm{pH}$, buffer capacity, calcium, total protein content and total anti-oxidant capacity in relation to dental caries severity, age and gender. Contemporary Clinical Dentistry. 2015 Vol 6(5): 65-71.

15. Balfe A, Barry S, Blake O, Cannon D, Healy M, Kibane $\mathrm{M}$ et al, The Biochemistry. 2 